\title{
Biochemical Changes during Traditional Fermentation of Saudi Sorghum (Sorghum bicolor L.) Cultivars Flour into Khamir (Local Gluten Free Bread)
}

\author{
Salah A. Almaiman, Ibrahim Abdel Rahman, Mostafa Gassem, Dalal, Alkhudayri,
} Haya F. Alhuthayli, Mohammed Awad Mohammed, Amro B. Hassan, Adil Fickak, and Magdi Osman* Department of Food Science and Nutrition, Faculty of Food and Agricultural Sciences, King Saud University, P.O. Box 2460, Riyadh 11451,
Kingdom of SAUDI ARABIA

\begin{abstract}
Effect of traditional fermentation on pH, titratable acidity, proteins, amino acids, and sugars contents of three local sorghum cultivars namely Hamra, Biadah and Shahla used in making khamir local bread were investigated. During 24 fermentations, the pH of fermented dough dropped sharply and this was coincided with increase in total acidity. Fermentation was found to cause no significant change in protein content of the cultivars. Amino acid analysis, revealed slight insignificant improvement in lysine, and leucine content but there was a slight decrease in valine, phenyl alanine and arginine content in fermented dough. Glucose, fructose and maltose content of the three sorghum cultivars increased considerably in the early stages of fermentation, followed by decrease towards the end of fermentation. Low amount of sucrose detected in the three cultivars and it was completely utilized after 8 hrs. of fermentation.
\end{abstract}

Key words: sorghum, fermentation, amino acids, sugars

\section{Introduction}

Sorghum (Sorghum bicolor L. Moench) is the most important stable food for more than 500 million people in the semi-arid and arid lands in Africa and Asia, primarily the low income people ${ }^{1)}$. Sorghum produces well with limited moisture and tolerant to salinity and high temperature stress. The sorghum production is around 54 million tons, from crop grown in about 40 million ha, and ranked the fifth most important cereal grown in the world ${ }^{2)}$. The nutrient composition of the sorghum revealed that it is an important source of energy, protein and mineral, vitamins and phytochemicals. Recently, sorghum has drawn special attention due to its gluten-free nature ${ }^{3)}$, low glycemic index ${ }^{4)}$, and as rich source of health promoting antioxidants because due the presence of phenolic acids and tannins specially, in the pigmented varieties ${ }^{5)}$.

Sorghum is traditionally fermented or germinated prior to consumption. Fermented sorghum is used in making various traditional foods, alcoholic and nonalcoholic beverage around the world, such Kisra in Sudan, Injera in Ethio- pia, fin in India, Mahewu in Zimbabwe, Dolo and pito in west Africa and lahloh and Khamir in Saudi Arabia ${ }^{6)}$. Fermentation process of sorghum flour had been reported to improve its nutritional quality and reduce antinutritional factors. Fermentation of sorghum for 36 or 24 hrs was also found to increase protein and starch in vitro digestibility and decrease antinutritional factors such as phytic acid, tannins, enzyme inhibitors ${ }^{6,7)}$. Inyang and Zakary ${ }^{8)}$ reported an increased in protein during natural fermentation of millet. Similarly, Cui et al. ${ }^{9)}$ observed an increase in in protein content and most of amino acids especially lysine in maize after three days' fermentation.

In Saudi Arabia, there are three sorghum cultivars Hamra, Bidaha and Shahla are grown in South-West region of Jazan, where it is traditionally utilized to prepare fermented traditional bread known as Khamir. The bread is prepared by mixing the sorghum flour with water, onion, lemon juice and fenugreek and fermented for $24 \mathrm{hr}$. The microbiological analysis of the micro-organisms involved in fermentation process of Khamir bread showed that lactic

\footnotetext{
*Correspondence to: Magdi Osman, Department of Food Science and Nutrition, Faculty of Food and Agricultural Sciences, King Saud University, P.O. Box 2460, Riyadh 11451, Kingdom of SAUDI ARABIA

E-mail: magdios@ksu.edu.sa

Accepted December 2, 2020 (received for review November 3, 2020)

Journal of Oleo Science ISSN 1345-8957 print / ISSN 1347-3352 online

http://www.jstage.jst.go.jp/browse/jos/ http://mc.manusriptcentral.com/jjocs
} 


\section{S. A. Almaiman, I. A. Rahman, M. Gassem et al.}

acid bacteria dominated over Enterobacteriaceae groups, yeasts and molds ${ }^{10)}$. Fermentation process was also found to decrease antinutritional factors and increase protein digestibility $^{11,12)}$. However, there is no information is available regarding the biochemical changes occurring during traditional fermentation of sorghum in to Khamir bread. Therefore, the objectives of this study were to investigate the changes in $\mathrm{pH}$, titerable acidity, proteins content, soluble sugars and amino acids content, occurring during traditional fermentation of sorghum cultivars mainly Hamra, Baidha and Shahla in to Khamir bread

\section{Materials and Methods}

\subsection{Materials}

The three sorghum varieties, Hamra, Baidha and Shahla used for this study were obtained from a local market in Jazan province (South-west Saudi Arabia). The grain was manually cleaned from impurities and milled and the flour was then transferred to laboratory in Riyadh and stored at $25^{\circ} \mathrm{C}$ until used.

\subsection{Fermentation}

Natural fermentation was carried out using the traditional process used by housewives as described by Osman ${ }^{11}$, briefly sorghum dough was prepared by mixing the flour with water and spices (fenugreek, onion and lemon juice) (1:0.8 ratio). The fermentation was carried out by adding $3 \%$ inocula from previous fermentation as a starter to the dough and incubated at $37^{\circ} \mathrm{C}$ for 24 hours. The fermented dough is made into pancake shape with $2-3 \mathrm{~cm}$ thickness by hand and baked in clay or mud oven known as tann our for 15 min. Fermentation was performed in duplicate and sampled every $4 \mathrm{hr}$ during fermentation period (24 hr). Samples were dried in a vacuum oven at $50^{\circ} \mathrm{C}$ (Heraucus LBS Co.), and milled to fine powder using a coffee miller then passed through a $60 \mathrm{~mm}$ mesh and kept at $4{ }^{\circ} \mathrm{C}$ in polyethylene bags for analysis.

\subsection{Determination of $\mathrm{pH}$ and titratable acidity}

The $\mathrm{pH}$ was monitored every $4 \mathrm{~h}$ interval using a digital pH-meter (JenwayPH10 flested UK.). Titratable acidity was determined according to $\mathrm{AOAC}^{13)}$. The titratable acidity was calculated as percent lactic acid.

\subsection{Protein content}

The crude protein of raw and fermented sorghum flour was determined by micro-Kjeldahl method as described by $\mathrm{AOAC}^{13)}$.

\subsection{Amino acid}

Amino acids composition was determined following the $\mathrm{AOAC}^{14)}$ method. Using HPLC (Shimadzu LC-10AD, Shi- madzu Corporation, Kyoto, Japan) in duplicate samples after hydrolyzed with $6.0 \mathrm{~N} \mathrm{HCL}$ at $100^{\circ} \mathrm{C}$ for $24 \mathrm{hrs}$.

\subsection{Determination of sugars}

Glucose, sucrose, fructose and maltose content of raw and fermented sorghum flour were analyzed according to $\mathrm{AOAC}^{13)}$, using HPLC Shimadzu LC from Shimadzu, KyotoJapan. Sugar standards were purchased from Sigma (Sigma Chemical Co., St. Louis, Mo).

\subsection{Statistical analysis}

Data, expressed as mean and standard deviation, were statistically analyzed using one-way ANOVA Steel and Torri ${ }^{15)}$. Duncan's multiple tests were used to compare means and significance was accepted at $p<0.05$.

\section{Results and Discussion}

\subsection{Effect of fermentation on the $\mathrm{pH}$ and titrable acidity of sorghum cultivars}

The effect of fermentation on $\mathrm{pH}$ and titrable acidity of Hamra, Baidha and Shahla is presented in Figs. 1 and 2. In general, there was progressive decrease in $\mathrm{pH}$ with increase of fermentation time in the three sorghum cultivars. The $\mathrm{pH}$ of fermented dough of the three cultivars were was decreased and reached 4.43, 4.65 and 4.47 at the end of 24 hr fermentation for Hamra, Bidah and Shahla respectively. The $\mathrm{pH}$ dropped sharply at first from $8 \mathrm{~h}$ and then, there was slight insignificantly $(p<0.05)$ decrease up to $24 \mathrm{~h}$ in the three cultivars. The decrease in $\mathrm{pH}$ was concomitant with increase in titerable acidity. The titerable increased significantly $(p<0.05)$ from initial values $0.26,0.27$ and 2.0 to final values $1.37,1.70$ and 1.65 during $24 \mathrm{~h}$ fermentation for Hamra, Biadha and Shahla respectively. Similar observations were reported for several other cereals. Fadlalla et $a l .{ }^{16)}$ observed that the $\mathrm{pH}$ of sorghum dropped from 6.05 to 3.79 and that of the sorghum supplemented with chickpea from 6.07 to 3.81 at the end of fermentation period (24 h). Similarly, Tou et $a l .{ }^{17)}$ reported decrease in $\mathrm{pH}$ and increase titrable acidity during preparation ben-saalga, a traditional fermented millet-based gruel. According to Gassem ${ }^{10)}$ increase in titerable acidity at the end fermentation of sorghum dough in to Khamir bread is due to accumulation of lactic acid produced by increased number of lactic acid bacteria during fermentation. The final $\mathrm{pH}$ values of fermented sorghum cultivars dough mix were slightly higher than the safe inhibitory $\mathrm{pH}(3.6$ to 4.1$)$ for pathogenic bacteria. The high $\mathrm{pH}$ could be attributed to low lactic acid concentration due to shorter period of fermentation, the temperature or to the presence of other ingredients such as onion, lemon juice and fenugreek.in dough mix that may slow the fermentation process. Lactic acid is responsible for the desirable sour taste and the 


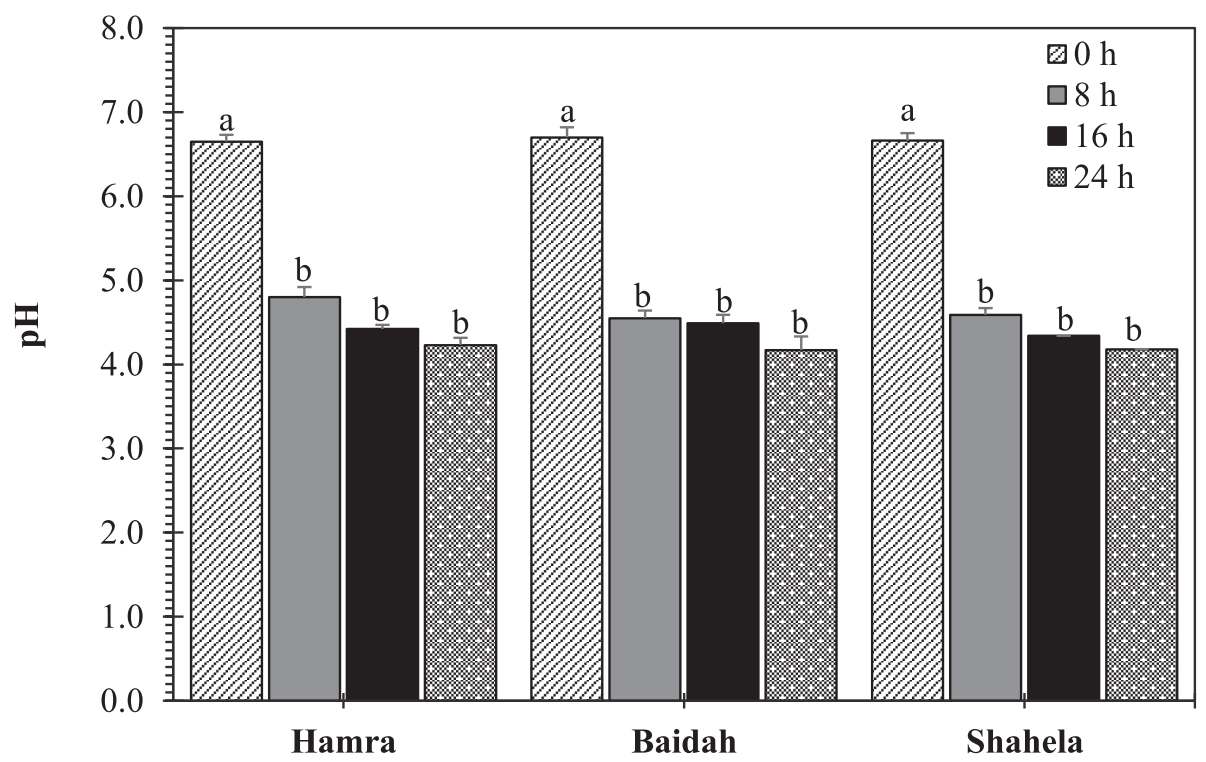

Fig. 1 Effect of fermentation for different period of time(hours) on $\mathrm{pH}$ of sorghum varieties. Values are means $( \pm \mathrm{SD})$ of triplicate samples. Values followed by the same letter are not significantly different $(p<0.05)$ as assessed by LSD.

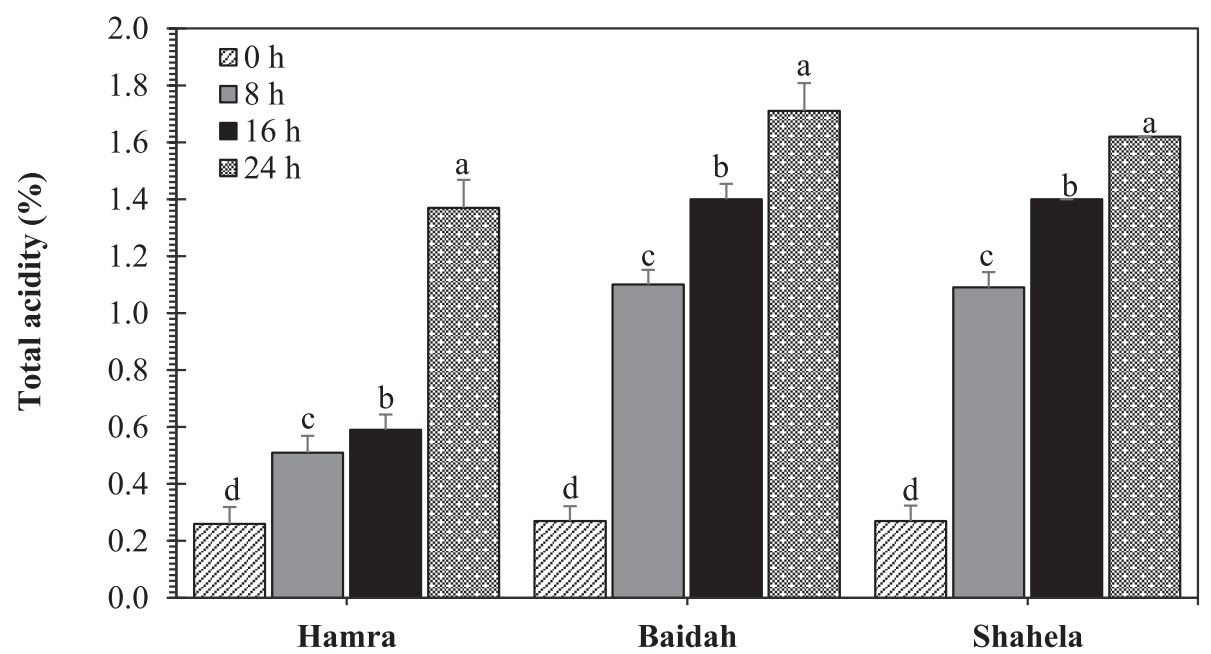

Fig. 2 Effect of fermentation for different period of time(hours) on total acidity of sorghum varieties. Values are means $( \pm$ SD) of triplicate samples. Values followed by the same letter are not significantly different $(p<0.05)$ as assessed by LSD.

special flavor of the bread that are important for in utilization and acceptability.

\subsection{Effect of fermentation on crude proteins of sorghum cultivars}

The change in protein contents of sorghum cultivars as function of fermentation time is shown in Table 1. The protein content of unfermented Hamra, Biadha and Shahla were $14.7,15.0$ and 14.95 respectively. Results obtained were within the range reported by Gassem and Osman ${ }^{12)}$ and Basahy ${ }^{18)}$. For the three cultivars, fermentation up to $24 \mathrm{~h}$ caused insignificant $(p>0.05)$ change in the content of protein. The protein content ranged from 14.71 to $14.90 \%$ at the end of fermentation period $(24 \mathrm{~h})$. This finding agree with that of Abdel Rahman and Osman ${ }^{19)}$, who reported the total protein content of was not significantly changed when three sorghum varieties fermented for $24 \mathrm{~h}$ for making Kissra. Hassan et $a l .{ }^{20)}$ also reported that the protein content of millet was not affected by fermentation. In same way, Yousif and El Tinay ${ }^{21)}$ and Ibrahim et al. ${ }^{22)}$ reported that the protein content of protein content of Dabar sorghum cultivar was fluctuated during the $24 \mathrm{~h}$ fermentation. However, prolonged fermentation time to $32 \mathrm{~h}$ slightly increase the protein content of sorghum dough. The slight insignificant reduction in protein content observed in this study could be attributed to the utilization of protein by microorganism for growth. 


\section{S. A. Almaiman, I. A. Rahman, M. Gassem et al.}

Table 1 Effect of fermentation for different period of time(hours) on crude protein (\%) of sorghum varieties.

\begin{tabular}{cccc}
\hline \multirow{2}{*}{$\begin{array}{c}\text { Fermentation time } \\
\text { (h) }\end{array}$} & \multicolumn{3}{c}{ Sorghum cultivars } \\
\cline { 2 - 4 } & Hamra & Baidah & Shahla \\
\hline $\mathbf{0}$ & $14.17 \pm 0.10^{\mathrm{a}}$ & $15.00 \pm 0.11^{\mathrm{a}}$ & $14.95 \pm 0.21^{\mathrm{a}}$ \\
$\mathbf{8}$ & $14.00 \pm 0.07^{\mathrm{a}}$ & $15.09 \pm 0.17^{\mathrm{a}}$ & $15.79 \pm 0.17^{\mathrm{a}}$ \\
$\mathbf{1 6}$ & $15.13 \pm 0.34^{\mathrm{a}}$ & $14.79 \pm 0,17^{\mathrm{a}}$ & $15.90 \pm 0.11^{\mathrm{a}}$ \\
$\mathbf{2 4}$ & $14.09 \pm 0.04^{\mathrm{a}}$ & $14.86 \pm 0.00^{\mathrm{a}}$ & $14.71 \pm 0.36^{\mathrm{a}}$ \\
\hline
\end{tabular}

Values are means \pm SD of three replicates. Values not sharing a common superscript letter are significantly different at $p<0.05$.

Table 2 Effect of fermentation for different period of time(hours) on amino acid profile ( $\mathrm{g} / 100 \mathrm{~g}$ protein) of sorghum varieties.

\begin{tabular}{|c|c|c|c|c|c|c|c|c|c|}
\hline \multirow[b]{3}{*}{ Amino acid } & \multicolumn{9}{|c|}{ Sorghum cultivars } \\
\hline & \multicolumn{3}{|c|}{ Hamra } & \multicolumn{3}{|c|}{ Baidah } & \multicolumn{3}{|c|}{ Shahla } \\
\hline & $0 \mathrm{~h}$ & $12 \mathrm{~h}$ & $24 \mathrm{~h}$ & $\mathbf{0 h}$ & $12 \mathrm{~h}$ & $24 \mathrm{~h}$ & O h & $12 \mathrm{~h}$ & $24 \mathrm{~h}$ \\
\hline Aspartic acid & $6.5 \pm 0.44^{\mathrm{a}}$ & $6.35 \pm 0.53^{\mathrm{a}}$ & $6.6 \pm 0.10^{\mathrm{a}}$ & $6.1 \pm 0.05^{\mathrm{a}}$ & $6.3 \pm 0.05^{\mathrm{a}}$ & $6.1 \pm 0.10^{\mathrm{a}}$ & $6.37 \pm 0.06^{\mathrm{a}}$ & $5.89 \pm 0.10^{\mathrm{a}}$ & $6.22 \pm 0.12^{\mathrm{a}}$ \\
\hline Threonine & $2.9 \pm 0.20^{\mathrm{a}}$ & $2.85 \pm 0.15^{\mathrm{a}}$ & $2.9 \pm 0.05^{\mathrm{a}}$ & $2.8 \pm 0.05^{\mathrm{a}}$ & $2.8 \pm 0.10^{\mathrm{a}}$ & $2.8 \pm 0.05^{\mathrm{a}}$ & $2.94 \pm 0.05^{\mathrm{a}}$ & $2.73 \pm 0.02^{\mathrm{a}}$ & $2.88 \pm 0.12^{\mathrm{a}}$ \\
\hline Serine & $3.7 \pm 0.30^{\mathrm{a}}$ & $3.7 \pm 0.20^{\mathrm{a}}$ & $3.8 \pm 0.10^{\mathrm{a}}$ & $3.5 \pm 0.05^{\mathrm{a}}$ & $3.5 \pm 0.15^{\mathrm{a}}$ & $3.6 \pm 0.30^{\mathrm{a}}$ & $3.76 \pm 0.04^{\mathrm{a}}$ & $3.47 \pm 0.06^{\mathrm{a}}$ & $3.58 \pm 0.14^{\mathrm{a}}$ \\
\hline Glutamic acid & $20.1 \pm 1.3^{\mathrm{a}}$ & $20.15 \pm 0.9^{\mathrm{a}}$ & $21.2 \pm 0.4^{\mathrm{a}}$ & $20.0 \pm 0.3^{\mathrm{a}}$ & $20.1 \pm 0.6^{\mathrm{a}}$ & $20.2 \pm 0.6^{\mathrm{a}}$ & $20.4 \pm 0.21^{\mathrm{a}}$ & $19.23 \pm 0.2^{\mathrm{a}}$ & $20.5 \pm 0.07^{\mathrm{a}}$ \\
\hline Glycine & $2.7 \pm 0.15^{\mathrm{a}}$ & $2.65 \pm 0.15^{\mathrm{a}}$ & $2.8 \pm 0.21^{\mathrm{a}}$ & $2.6 \pm 0.05^{\mathrm{a}}$ & $2.8 \pm 0.05^{\mathrm{a}}$ & $2.3 \pm 0.20^{\mathrm{a}}$ & $2.75 \pm 0.14^{\mathrm{a}}$ & $2.42 \pm 0.02^{\mathrm{a}}$ & $2.55 \pm 0.11^{\mathrm{a}}$ \\
\hline Alanine & $8.6 \pm 0.65^{\mathrm{a}}$ & $8.45 \pm 0.51^{\mathrm{a}}$ & $8.8 \pm 0.21^{\mathrm{a}}$ & $8.3 \pm 0.10^{\mathrm{a}}$ & $8.4 \pm 0.13^{\mathrm{a}}$ & $8.3 \pm 0.10^{\mathrm{a}}$ & $8.73 \pm 0.09^{\mathrm{a}}$ & $8.14 \pm 0.05^{\mathrm{a}}$ & $8.50 \pm 0.25^{\mathrm{a}}$ \\
\hline Valine & $5.0 \pm 0.21^{\mathrm{a}}$ & $4.9 \pm 0.30^{\mathrm{a}}$ & $4.9 \pm 0.15^{\mathrm{a}}$ & $4.8 \pm 0.10^{\mathrm{a}}$ & $4.6 \pm 0.32^{\mathrm{a}}$ & $4.5 \pm 0.31^{\mathrm{a}}$ & $5.02 \pm 0.07^{\mathrm{a}}$ & $4.60 \pm 0.08^{\mathrm{a}}$ & $5.00 \pm 0.30^{\mathrm{a}}$ \\
\hline Methionine & $1.5 \pm 0.31^{\mathrm{a}}$ & $1.35 \pm 0.5^{\mathrm{a}}$ & $1.4 \pm 0.1^{\mathrm{a}}$ & $1.8 \pm 0.05^{\mathrm{a}}$ & $1.7 \pm 0.02^{\mathrm{a}}$ & $1.5 \pm 0.31^{\mathrm{a}}$ & $1.75 \pm 0.03^{\mathrm{a}}$ & $1.57 \pm 0.01^{\mathrm{a}}$ & $1.65 \pm 0.05^{\mathrm{a}}$ \\
\hline Isoleucine & $3.7 \pm 0.15^{\mathrm{a}}$ & $3.55 \pm 0.25^{\mathrm{a}}$ & $3.5 \pm 0.10^{\mathrm{a}}$ & $3.8 \pm 0.05^{\mathrm{a}}$ & $3.7 \pm 0.02^{\mathrm{a}}$ & $3.6 \pm 0.05^{\mathrm{a}}$ & $3.70 \pm 0.06^{\mathrm{a}}$ & $3.46 \pm 0.05^{\mathrm{a}}$ & $3.73 \pm 0.10^{\mathrm{a}}$ \\
\hline Leucine & $12.6 \pm 0.9^{\mathrm{a}}$ & $12.5 \pm 0.8^{\mathrm{a}}$ & $12.9 \pm 0.1^{\mathrm{a}}$ & $12.5 \pm 0.2^{\mathrm{a}}$ & $12.7 \pm 0.2^{\mathrm{a}}$ & $12.7 \pm 0.5^{\mathrm{a}}$ & $13.18 \pm 0.1^{\mathrm{a}}$ & $12.17 \pm 0.1^{\mathrm{a}}$ & $13.65 \pm 0.9^{\mathrm{a}}$ \\
\hline Tyrosine & $3.1 \pm 0.25^{\mathrm{a}}$ & $3.0 \pm 0.20^{\mathrm{a}}$ & $3.3 \pm 1.21^{\mathrm{a}}$ & $3.2 \pm 0.05^{\mathrm{a}}$ & $3.2 \pm 0.15^{\mathrm{a}}$ & $3.2 \pm 0.05^{\mathrm{a}}$ & $3.36 \pm 0.06^{\mathrm{a}}$ & $2.70 \pm 0.20^{\mathrm{a}}$ & $3.27 \pm 0.07^{\mathrm{a}}$ \\
\hline Phenylalanine & $5.0 \pm 0.40^{\mathrm{a}}$ & $4.5 \pm 0.81^{\mathrm{a}}$ & $5.2 \pm 0.11^{\mathrm{a}}$ & $5.0 \pm 0.10^{\mathrm{a}}$ & $5.3 \pm 0.12^{\mathrm{a}}$ & $4.9 \pm 0.05^{\mathrm{a}}$ & $5.06 \pm 0.06^{\mathrm{a}}$ & $4.70 \pm 0.10^{\mathrm{a}}$ & $4.98 \pm 0.02^{\mathrm{a}}$ \\
\hline Histidine & $2.1 \pm 0.10^{\mathrm{a}}$ & $2.1 \pm 0.10^{\mathrm{a}}$ & $2.1 \pm 0.00^{\mathrm{a}}$ & $2.1 \pm 0.10^{\mathrm{a}}$ & $2.1 \pm 0.04^{\mathrm{a}}$ & $1.9 \pm 0.11^{\mathrm{a}}$ & $2.00 \pm 0.02^{\mathrm{a}}$ & $1.84 \pm 0.04^{\mathrm{a}}$ & $2.00 \pm 0.03^{\mathrm{a}}$ \\
\hline Lysine & $2.1 \pm 0.15^{\mathrm{a}}$ & $2.2 \pm 0.10^{\mathrm{a}}$ & $2.2 \pm 0.05^{\mathrm{a}}$ & $1.9 \pm 0.05^{\mathrm{a}}$ & $1.9 \pm 0.10^{\mathrm{a}}$ & $2.0 \pm 0.08^{\mathrm{a}}$ & $1.85 \pm 0.00^{\mathrm{a}}$ & $1.85 \pm 0.02^{\mathrm{a}}$ & $2.00 \pm 0.03^{\mathrm{a}}$ \\
\hline Arginine & $5.2 \pm 0.25^{\mathrm{a}}$ & $5.1 \pm 0.20^{\mathrm{a}}$ & $4.8 \pm 0.05^{\mathrm{a}}$ & $5.1 \pm 0.05^{\mathrm{a}}$ & $4.9 \pm 0.31^{\mathrm{a}}$ & $3.2 \pm 0.20^{\mathrm{a}}$ & $4.87 \pm 0.03^{\mathrm{a}}$ & $4.47 \pm 0.10^{\mathrm{a}}$ & $4.80 \pm 0.14^{\mathrm{a}}$ \\
\hline Proline & $6.7 \pm 0.15^{\mathrm{a}}$ & $6.6 \pm 0.25^{\mathrm{a}}$ & $6.8 \pm 0.40^{\mathrm{a}}$ & $5.3 \pm 0.15^{\mathrm{a}}$ & $5.8 \pm 0.10^{\mathrm{a}}$ & $5.6 \pm 0.05^{\mathrm{a}}$ & $6.18 \pm 0.06^{\mathrm{a}}$ & $5.65 \pm 0.05^{\mathrm{a}}$ & $5.91 \pm 0.12^{\mathrm{a}}$ \\
\hline
\end{tabular}

Values are means \pm SD of three replicates. Values sharing a common superscript letter are insignificantly different at $p<0.05$.

3.3 Effect of fermentation on Amino acids profile of sorghum cultivars

The effect of fermentation on amino acids content of Hamra, Biadha and Shahla sorghum cultivars is presented in Table 2. The amino acids composition of the unfermented sorghum flours showed that glutamic acids, leucine, alanine and aspartic acids were the major amino acids. The amino acids profile of the sorghum the three cultivars are in agreement with those reported by Abdel Rahman and Osman $^{23)}$. Fermentation process resulted in slight insignificant increase, leucine and lysine. Similarly, Fadlallah et $a l .{ }^{16)}$ could not find any definite trend in amino acids during $24 \mathrm{~h}$ fermentation of sorghum and sorghum-chickpea blends. Cui et al. ${ }^{9)}$, however, reported significant increase in most of the amino acids with largest increase in lysine, during 3 days' fermentation of maize. Similarly, Hamad and Field ${ }^{24)}$ reported that natural fermentation of wheat, oats, sorghum and rice for 6 days significantly increased the essential amino acids, and available lysine content. On the contrary, Osman ${ }^{25)}$, observed significant decrease in lysine, arginine and glycine after $24 \mathrm{~h}$ fermentation in millet dough. The slight change in amino acids content observed is probably due to short fermentation period used in this study.

\subsection{Effect of fermentation on soluble sugars content of sorghum cultivars}

The effect of fermentation on glucose, fructose, sucrose and maltose content of Hamra, Biadah and Shahla is presented in Fig. 3 (A, B and C). The analysis of soluble sugars revealed that glucose is major soluble sugar in the three sorghum cultivars. The glucose content of unfermented Hamra, Biadha and Shahla dough was found to be 1.20 , 1.58 and $1.12 \mathrm{gm} / 100 \mathrm{gm}$ sample respectively. In the three 

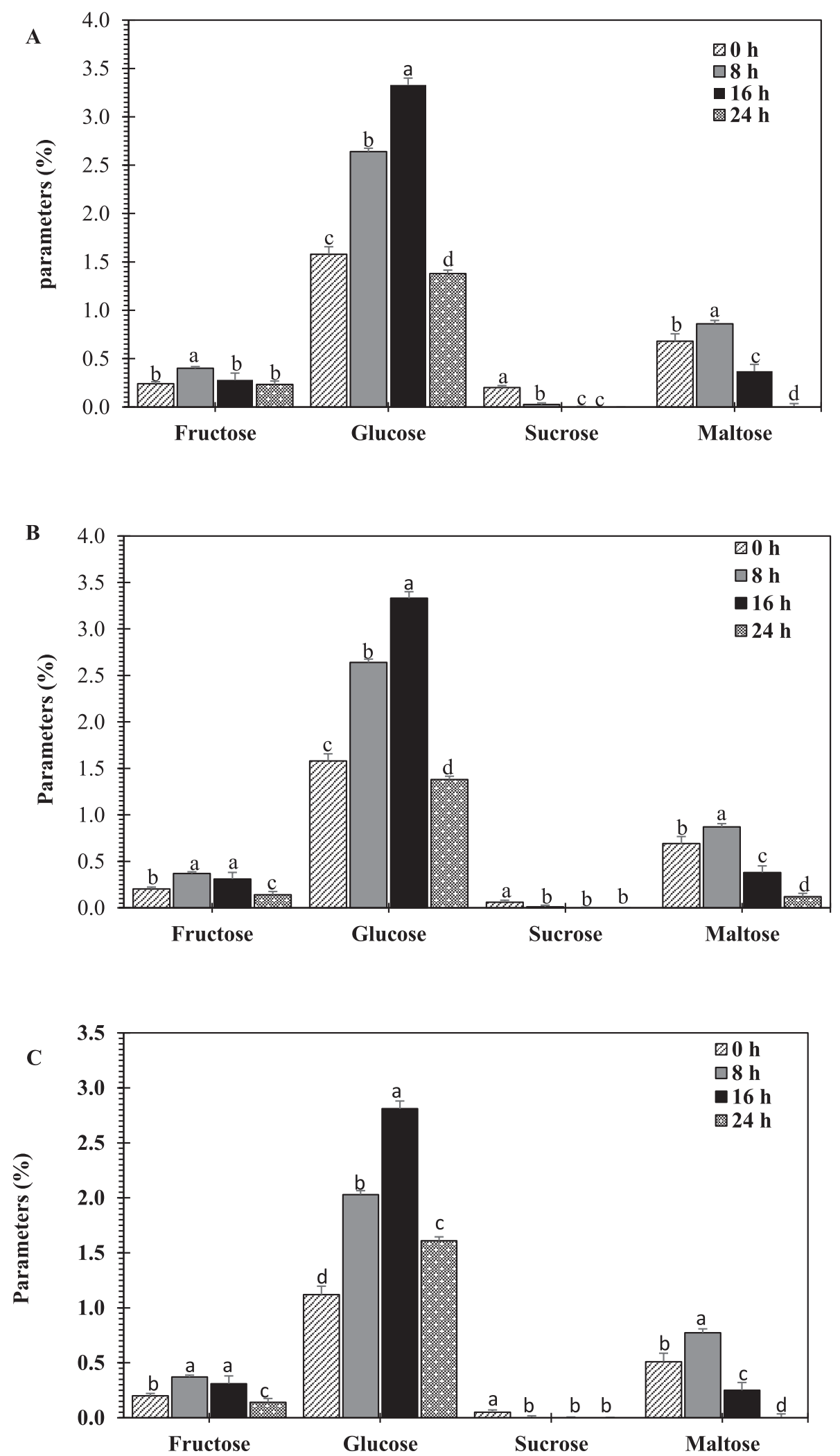

Fig. 3 Effect of fermentation for different period of time(hours) on soluble sugars of sorghum varieties (A) Hamra, (B) Baidah and $(\mathrm{C})$ Shahela. Values are means $( \pm \mathrm{SD})$ of triplicate samples. Values followed by the same letter are not significantly different $(p<0.05)$ as assessed by LSD. 


\section{S. A. Almaiman, I. A. Rahman, M. Gassem et al.}

cultivars, the concentration of glucose increased sharply during early stages of fermentation and reached a maximum after $16 \mathrm{~h}$ and thereafter decreased. The increase of glucose was greater in Shahla (150.9\%) compared to Hamra (116.7\%) and Bidah (110.2\%). Similar to glucose, there was a sharp increase in fructose content in first 8 hrs of fermentation. It increased from 0.202 to 0.31 , from 0.24 to 0.4 and from 0.2 to 0.36 for Hamra, Biadah and Shahla respectively. Increasing fermentation period up to $24 \mathrm{~h}$ markedly caused a decrease in fructose content to 0.172 , 1.38 and 1.61 for the three cultivars. The result obtained here is in agreement with those of Osman et $a l .{ }^{19)}$ who reported that the level of reducing sugars showed an increased and then a decreased as the fermentation time increases, during Kissra preparation. Similarly, Hamad and Field $^{24}$ observed increase and the decrease in reducing sugars during fermentation of wheat, rice, oats and sorghum for 6 days. The increase glucose content could be attributed to the action of microbial $\alpha$ and $\beta$ amylase, sucrase and maltase, whereas the decrease at the end fermentation probably due to utilization of glucose as source of energy by microorganism.

Sucrose content was decreased rapidly and completely utilized after $8 \mathrm{~h}$ in the three cultivars. In contrast, the content of maltose increased sharply during the first $8 \mathrm{hr}$, it increased from 0.23 to 0.77 , from 0.68 to 0.86 and from 0.51 to 0.80 for Hamra, Baidah and Shahla respectively. However, when the fermentation was continued to $24 \mathrm{~h}$, the amount of maltose started to decrease at a steady rate and completely utilized at the end of fermentation period in both Biiadh and Shahla. Similar trend observed during fermentation of pearl millet to ben-salga, a fermented gruel $^{17)}$. The changes either as an increase or a decrease in maltose could be attributed to action of microorganism amylase that hydrolyzed starch to maltose and to the action of maltase associated with fermentation.

Therefore, in order to increase the protein and essential amino acid content, such as lysine the first limiting amino acids of fermented sorghum, the fermentation process should be carried out between 3-6 days or by using a fermenter with pure bacteria culture and controlled parameters for industrial application. The fermented sorghum flour could be utilized in formulation of weaning food, blend with wheat to produce cheap and nutritious bread, blended with local legumes for combating protein malnutrition in poor countries or help in solving major problem for celiac patient, due to the fact that the local bread is gluten free that has the poetical for commercial application.

\section{Conclusion}

Fermentation process of the three sorghum cultivars during preparation of the khamir gluten free bread resulted in decrease in $\mathrm{pH}$, which was accompanied by increase in titerable acidity contents. The traditional fermentation process of sorghum cultivars was found to cause no significant change in protein. Amino acid analysis of fermented sorghum revealed slight insignificant increase in the content of some of the amino acids and decrease in others in three dough samples. Sugars study showed remarkable changes in soluble sugars content in the three sorghum varieties. These results indicated the need for longer fermentation time or addition of other process such as soaking or germination before fermentation to increase nutritional quality. The results indicate that fermentation for longer period would contribute in increasing protein and essential amino acids such as lysine the first limiting amino acid in cereal of the three local sorghum cultivars, that could be used in developing new cheap bakery products by mixing with wheat, in poor countries or weaning food for children in Asia and Africa by blending fermented sorghum flour with local legumes in order to combat protein malnutrition (Kawakshior).

\section{Acknowledgment}

The authors would like to extend their appreciation to the Deanship of Scientific Research at King Saud University for funding this work through research group NO. RG1441-.530.

\section{Conflict of Interest}

The authors declare that there is no conflict of interest.

\section{References}

1) Ashok Kumar, A.; Reddy, B.V.S.; Sharma, H.C. Recent advances in sorghum genetic enhancement research at ICRISAT. American J. Plant Sci. 2, 589-600 (2011).

2) FAOSTAT; http://faostat.fao.org/faostat/(2017) (Last accessed 25 January 2020).

3) Ciacci, C.; Maiuri, L.; Caporaso, N. Celiac disease: In vitro and in vivo safety and palatability of wheat-free sorghum food products. Clinical Nutri. 26, 799-805 (2007)

4) Serna-Saldivar, S.O.; Espinosa-Ramírez, J. Chapter 5 Grain structure and grain chemical composition. in Sorghum and Millets (Taylor, J.R.N.; Duodu, K.G. eds.) $2^{\text {nd }}$ ed. (2019)

5) Kumar, A.; Anuradha, K.; Ramaiah, B. Recent Advances in Sorghum Biofortification Research. In: Plant Breeding Reviews: Volume 39. John Wiley \& Sons, Ltd., pp. 89-124(2015). 
6) Adebo, O.A. African sorghum-based fermented foods: Past, current and future prospects. Nutients 12, 111 (2020).

7) Pranoto, Y.; Anggrahini, S.; Efendi, Z. Effect of natural fermentation and Lactobacillus plantarum on in vitro protein and starch digestibility of sorghum flour. Food Biosci. 2, 45-52 (2013).

8) Inyang, C.U.; Zakari, U.M. Effect of germination and fermentation of pearl millet on proximate, chemical and sensory properties of instant "Fura"-A cereal food. Pakistan J. Nutri. 7, 9-12(2008).

9) Cui, L.; Li, D.; Li, D. Effect of fermentation on nutritive value of maize. Food Sci. Technol. 47, 755-760 (2012).

10) Gassem, M.A. Study of the micro-organisms associated with the fermented bread (khamir) produced from sorghum in Gizan region, Saudi Arabia. J. Appl. Microbiol. 86, 221-225 (1999).

11) Osman, M.A. Changes in sorghum enzyme inhibitors, phytic acid, tannins, and in vitro protein digestibility occurring during Khamir(local bread)fermentation. Food Chem. 88, 129-134(2004).

12) Gassem, M.A.; Osman, M.A. Chemical composition sand nutritional potential of pearl millet grown in Jazan region of Saudi Arabia. J. Saudi Society Agric. Sci. 7, 1-22 (2008).

13) AOAC. Official Methods for Analysis ( $16^{\text {th }}$ ed.). Association of Official Analytical Chemists. Arlington VA. $\operatorname{USA}(2005)$.

14) AOAC. Official Methods of Analysis of AOAC International. AOAC 53 International, Gaithersburg, Maryland, USA (2012).

15) Steel, R.G.; Torri, J.H. Principles and procedures of statistics. McGraw-Hill. Book Co. Inc., New York. USA (1980).

16) Fadlallah, O.E.; El Tinay, A.H.; Babiker, E.E. Biochemical characteristics of sorghum flour fermented and/or supplemented with chickpea flour. Intern. J. Biol. Life Sci. 6, 21-25 (2010).
17) Tou, E.H.; Mauquet-Rivier, C.; Picq, C.; Traore, A.S.; Treche, S.; Guyot, J.P. Improving the nutritional quality of ben-saalga, a traditional fermented millet-based gruel, by co-fermenting with groundnut and modifying the process method. LWT Food Sci. Tech. 40, 15611569 (2007).

18) Basahy, A. Chemical composition of some sorghum grains (Sorghum bicolor (L) Moench Poaceae) grown in Gizan area, Saudi Arabia. Arab Gulf J. Sci. Res. 13, 151-161 (1995).

19) Osman, M.A.; Abdel-Rahman, I.E.; Hamad, S.H.; Dirar, H.A. Biochemical changes occurring during traditional Sudanese processing of Kisra. International J. Food Agric. Environ. 8, 102-106(2011).

20) Hassan, A.B.; Mohamed Ahmed, I.A.; Osman, N.M.; Eltayeb, M.M.; Osman, G.A; Babikker, E.E. Effect of processing treatment followed by fermentation on protein content and digestibility of pearl millet(Pennisetum typhoideum) cultivars. Pakistan J. Nutri. 5, 86-89 (2006).

21) Yousif, N.A.; El Tinay, A.H. Effect of fermentation on sorghum protein fractions and in vitro protein digestibility. Plant Foods Hum. Nutr. 56, 175-182 (2001).

22) Ibrahim, F.S.; Babiker, E.E.; Yousif, N.E.; El Tinay, A.H. Effect of whey protein supple-mentation and/or fermentation on bio-chemical and sensory characteristics of sorghum flour. Food Chem. 92, 285-292 (2005).

23) Abdel-Rahman, I.E.; Osman, M.A. Changes in chemical composition, available carbohydrates and amino acids during soaking and germination of Saudi sorghum cultivars. J. Saud. Society Food Nutr. 5(2), 1-12(2010).

24) Hamad, M.A.; Fields, M.I. Evaluation of protein quality and available lysine of germinated and fermented cereals. J. Food Sci. 44, 456-460 (1979).

25) Osman, M.A. Effect of traditional fermentation on nutrient and antinutrients of pearl millet during preparation of Lohoh (Local bread). J. Saudi Soci Agric Sci. 10, 1-13(2011). 